\title{
A Phenomenological Study on Chinese Private College Students' Experiences in Developing Intercultural Competence
}

\author{
$\mathrm{Li} \mathrm{Li}$ \\ Attallah College of Educational Studies, Chapman University, United States \& Sanda University, China \\ Email: lili@chapman.edu \\ Address: One University Drive, Orange, CA92866, United States \\ $\&$ \\ Room 339, Building 10, 2727 Jinhai Road, Pudong, Shanghai 201209, China
}

\section{Introduction}

This research is a phenomenological study about six students' experiences in learning English as a Foreign Language (EFL) in a private university in China and study abroad experiences in developing intercultural competence (IC). This paper consists of two parts. The first part introduces the research topic and purpose, research significance, and research questions. The second part discusses the research methodology and methods.

\section{Topic and Purpose}

With globalization and internationalization becoming the features of the 21 st century, intercultural communicative competence has become one of the core elements (Byram 2008). The United Nations Educational, Scientific, and Cultural Organization (UNESCO 2013, p. 5) states that intercultural competence can be seen as part of a broad toolkit of worldviews, attitudes, and competencies that young people acquire for their lifelong journey. The Program for International Student Assessment (PISA) includes global competence as a new domain in 2018 (OECD PISA 2018). Academic exchange and cooperation between China and other countries have become more frequent, which requires China to cultivate more talents with a global vision and high-level intercultural competence. Chinese higher education has been entrusted with the responsibility of cultivating international talents to serve China's international exchanges and cooperation worldwide.

In the higher education sector of China, students of public and private institutions account for $77 \%$ and $23 \%$ of all college student population respectively (Ministry of Education of China 2018). Research on Chinese college students' intercultural competence mainly focuses on the students in public institutions. However, private college students are an indispensable part of Chinese college students, whose intercultural competence is equally important.

According to Hu's (2010) study, China's intercultural competence studies have long been limited to foreign language education. Retrieved from the database of China National Knowledge Infrastructure from 2003 to 2012, the total number of published papers on intercultural competence or intercultural communication competence was 6,942. $80 \%$ of which was composed of papers on developing intercultural competence through foreign language education. As a large portion of foreign language teachers in China have not received systematic methodological trainings to conduct empirical research yet, empirical studies on intercultural competence in China are scarce.

Byram's (1997) intercultural competence model provides a solid theoretical basis for improving intercultural competence through foreign language learning. Intercultural competence development has become one of the core components in China's EFL education, according to three key policy documents about EFL education, issued by 
Ministry of Education of China (CITE). They include College English Curriculum Requirements (2017), National English-Teaching Syllabus for English Majors in Colleges and Universities (2000), and National Standards for the Quality of Undergraduate Teaching of Foreign Language and Literature Majors (2018).

To fill in the exsiting research gap of empirical studies on intercultural competence development of students in China's private colleges and universities, I intend to use a phenomenological methodology to explore their EFL learning experiences in China and study abroad experiences in developing intercultural competence.

\section{Significance of Study}

This study will provide practical significance in two aspects for the private higher education institutions in China. First, if the findings provide evidence that overseas experiences can contribute to the improvement of students' intercultural competence, policymakers may feel more confident in increasing investment in study abroad programs. If the findings do not support the positive influence of overseas experiences on students' intercultural competence development, this study may provide policymakers with directions on how to adjust the existing programs to maximize the benefits of participants' experiences. Second, this study can provide guidance for the improvement of EFL teaching and activities inside and outside classrooms to improve students' intercultural competence level in China's private colleges and universities.

\section{Research Questions}

Based on the research purpose, I will conduct a phenomenological study to address three questions:

1. What are the experiences of students with a high level of intercultural competence in EFL learning inside classrooms in China?

2. What are the experiences of students with a high level of intercultural competence in EFL activities outside classrooms in China?

3. What are the experiences of students in a study abroad program in the United States?

\section{Methodology}

I will use a phenomenological methodology for this study. In this part, I will present the rationale for using this methodology and a discussion of its elements, including site and sampling, data collection methods, and data analysis procedure.

\section{Rationale}

In a phenomenological study, researchers focus on describing the commonalities that all participants have as they experience a phenomenon (CITE). This description consists of what they experience and how they experience the phenomenon (Moustakas 1994). The choice of research methodology is driven by the research purpose and questions. Given that my research focuses on studying the lived experiences of students with high level of intercultural competence in China and the United States, using a phenomenological design is most appropriate for this study.

Site

There will be two research sites for this study. One site is SD University (SD), a private university in Shanghai, China, and the other site will be LD University (LD), a public university in South Carolina, United States. Since 2013, SD and LD have established a partnership program to accept up to 10 students to study at SD or LD for one or two semester(s) every year. I will do the first investigation at SD in Spring 2020 and the second investigation at LD in Fall 2020. 


\section{Sampling}

My whole research will use mixed methods, involving an intercultural competence survey at the beginning and end of the research, and conducting a qualitative inquiry on the same participants for two semesters between the two surveys. For this research proposal, I will focus on the qualitative methods. The participants for this study will be chosen through purposeful sampling.

\section{Data Collection Methods}

This study will conduct in-depth interviews and focus-group interviews to collect data. In-depth interviews will be used as the primary data collection method. Focu-group interviews will be used as the secondary method to validate findings from the in-depth interviews.

\section{Data Analysis Procedure}

The data analysis will start with organizing and coding the transcripts in an Excel spreadsheet, generating categories and themes, interrelating themes, and then interpreting the meaning of themes. I will write reflective memos to help understand how codes are grouped into categories and themes. I will follow the three steps proposed by Creswell (2007) to analyze the data.

\section{Conclusion}

In this paper, I present a phenomenological design to study on six Chinese private college students' EFL learning experiences in China and study abroad experiences in developing intercultural competence. Based on the research purpose, three research questions are proposed accordingly. Phenomenology is selected as an appropriate methodology for this study. The paper elaborates some essential components of this phenomenological design at this proposal stage.

\section{References}

Byram, Michael. 2008. From Foreign Language Education to Education for Intercultural Citizenship: Essays and Reflections. London, England: Multilingual Matter.

Creswell, John W. 2007. Qualitative Inquiry and Research Design: Choosing among Five Approaches. Thousand Oaks, CA: Sage.

Hu, Wen Zhong. 2010. "View the Present Situation and Future of Intercultural Communication from the Perspective of Discipline Construction. (in Chinese.)" Journal of Foreign Languages 33(6): 28-32.

Ministry of Education of the People's Republic of China. 2000. "National English-Teaching Syllabus for English Majors in Colleges and Universities. (in Chinese.)" Beijing, China.

Ministry of Education of the People's Republic of China. 2017. "College English Curriculum Requirements. (in Chinese.)" Beijing, China.

Ministry of Education of the People's Republic of China. 2018. "National Standards for the Quality of Undergraduate Teaching of Foreign Language and Literature Majors. (in Chinese.)" Beijing, China.

Ministry of Education of China. 2018. "Annual Publication of the Basic Situation of National Education Development. (in Chinese.)" Beijing, China.

Moustakas, Clark E. 1994. Phenomenological Research Methods. Thousand Oaks, CA: Sage.

OECD. 2018. "PISA." https://www.oecd.org/pisa/pisa-2018-global-competence.htm.

UNESCO. 2013. "Intercultural Competences, Conceptual and Operational Framework." https://unesdoc.unesco.org/ark:/48223/pf0000219768. 